The International Journal of

\title{
Organizational Diversity
}

Systemic Constellations in

Diversity Management 
EDITOR

Jock Collins, University of Technology, Australia

\section{MANAGING EDITOR}

Caitlyn D'Aunno, Common Ground Publishing, USA

\section{ADVISORY BOARD}

Ien Ang, University of Western Sydney, Australia Samuel Aroni, University of California, Los Angeles, USA Vivienne Bozalek, University of the Western Cape, South Africa Susan Bridges, University of Hong Kong, Hong Kong Duane Champagne, University of California, Los Angeles, USA Jock Collins, University of Technology, Australia Leonard Edmonds, Arizona State University, USA Grethe van Geffen, Seba Culturmanagement, The Netherlands Jackie Huggins, University of Queensland, Australia Andrew Jakubowicz, University of Technology, Australia Paul James, University of Western Sydney, Australia Ha Jingxiong, Central University of Nationalities, China Thomas Köllen, Vienna University of Economics and Business, Austria Jack Levin, Northeastern University, USA

José Luis Ortega Martin, University of Granada, Spain Fethi Mansouri, Deakin University, Australia Joe Melcher, Xavier University of Louisiana, USA Brendan O'Leary, University of Pennsylvania, USA Aihwa Ong, University of California, Berkeley, USA Peter Phipps, RMIT University, Australia

Michael Shapiro, University of Hawai'i at Mānoa, USA David S. Silverman, Kansas Wesleyan University, USA Roger Slee, Victoria University, Australia

Crain Soudien, University of Cape Town, South Africa Terry Threadgold, Cardiff University, UK Rob Walker, Keele University, UK Ning Wang, Tsinghua University, China

\section{ASSOCIATE EDITORS}

Articles published in The International Journal of Organizational Diversity are peer reviewed by scholars who are active participants of the Diversity in Organizations, Communities \& Nations Knowledge Community or a thematically related Knowledge Community. Reviewers are acknowledged as Associate Editors in the corresponding volume of the journal. For a full list, of past and current Associate Editors please visit www.ondiversity.com/journals/editors.

\section{ARTICLE SUBMISSION}

The International Journal of Organizational Diversity publishes quarterly (March, June, September, December). To find out more about the submission process, please visit www.ondiversity.com/journals/call-for-papers.

\section{THE INTERNATIONAL JOURNAL OF ORGANIZATIONAL DIVERSITY \\ www.ondiversity.com \\ ISSN: 2328-6261 (Print) \\ ISSN: 2327-6229 (Online) \\ doi:10.18848/2328-6261/CGP (Journal)}

First published by Common Ground Publishing in 2016 University of Illinois Research Park

2001 South First Street, Suite 202

Champaign, IL 61820 USA

$\mathrm{Ph}:+1-217-328-0405$

www.commongroundpublishing.com

The International Journal of Organizational Diversity is a peer-reviewed, scholarly journal.

\section{COPYRIGHT}

(C) 2016 (individual papers), the author(s)

(C) 2016 (selection and editorial matter), Common Ground Publishing

All rights reserved. Apart from fair dealing for the purposes of study, research, criticism, or review, as permitted under the applicable copyright legislation, no part of this work may be reproduced by any process without written permission from the publisher. For permissions and other inquiries, please contact cg-support@commongroundpublishing.com.

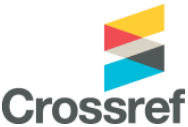

Common Ground Publishing is a member of Crossref.

\section{ABSTRACTING AND INDEXING}

For a full list of databases in which this journal is indexed, please visit www.ondiversity.com/journals/collection.

\section{KNOWLEDGE COMMUNITY MEMBERSHIP}

Authors in The International Journal of Organizational Diversity are members of the Diversity in Organizations, Communities \& Nations Knowledge Community or a thematically related Knowledge Community. Members receive access to journal content. To find out more, visit www.ondiversity.com/about/become-a-member.

\section{SUBSCRIPTIONS}

The International Journal of Organizational Diversity is available in electronic and print formats. Subscribe to gain access to content from the current year and the entire backlist. Contact us atcg-support@commongroundpublishing.com.

\section{ORDERING}

Single articles and issues are available from the journal bookstore at www.ijdo.cgpublisher.com.

\section{HYBRID OPEN ACCESS}

The International Journal of Organizational Diversity

is Hybrid Open Access, meaning authors can choose to make their articles open access. This allows their work to reach an even wider audience, broadening the dissemination of their research. To find out more, please visit www.ondiversity.com/journals/hybrid-open-access

\section{DISCLAIMER}

The authors, editors, and publisher will not accept any legal responsibility for any errors or omissions that may have been made in this publication. The publisher makes no warranty, express or implied, with respect to the material contained herein. 


\title{
Systemic Constellations in Diversity Management
}

\author{
Carmen A. Finckh, Reutlingen University, Germany \\ Kerstin Reich, Reutlingen University, Germany
}

\begin{abstract}
Systemic Constellation describes an approach that enables practitioners to examine and address typical issues in diversity management from a different, relational perspective. Systemic Constellation utilizes the human ability to recognize the qualities of relationships between two or more people from their spatial alignment to each other (transverbal language) and the capability to illustrate inner pictures by placing humans or objects in a room as representatives (representative perception). Systemic Constellation originated in the field of family therapy and counseling, but through research, guidance work, and teaching activities over the last two decades, it has developed into a generic, structural, constellation logic with multiple methods of application. It has been adapted to a variety of topics and issues, and a number of constellation formats. This article serves as a starting point for the transfer of Systemic Constellation into diversity management. It appears that conventional approaches taught in traditional management classes (such as focusing on tools, setting targets, planning measures, and offering incentives) are of limited use when trying to deal with problematic situations in diversity management. Preliminary trials show that new solutions and insights into deeper underlying dynamics can be gained on personal and institutional levels when applying Systemic Constellation. Participants find the application of the model as very beneficial. Systemic Constellation is grounded in personal experience and particularly in a person's own experience of the consistency of representative perception. This viewpoint can only be conveyed rudimentarily in a scientific article. Readers should feel encouraged to apply Systemic Constellations themselves and use it in their work, experimentally and professionally. To harness the full potential of Systemic Constellations in diversity management, further research needs to be done.
\end{abstract}

Keywords: Systemic Constellations, Systemic View, Systemic Management,

Diversity Management, Gender Diversity, Change Management

\section{Purpose of the Article}

$\mathrm{T}$ This article explores how Systemic Constellation can support practitioners in diversity management. It will show a way of getting new insights into existing diversity management issues. Diversity management includes a broad range of different aspects depending on the context in which people are living and working (e.g., Mazur 2012; Langholz 2014; Kupczyk et al. 2015; Archibong et al. 2016; McConatha and DiGregorio 2016). For example, managers in German companies face different diversity challenges depending on the industry, the strategy, and human resources policy their company follows compared to managers in other countries or companies. Gender diversity is at present one of the most discussed aspects in diversity management of German companies (Süß and Kleiner 2008; Vedder 2009; Ortlieb, Sieben, and Krell 2012).

Over the last years the authors have experienced, both as actors and researchers, gender diversity management in a German university. During the reflection process, the central theme of this article emerged, that (gender) diversity issues seem to be inherently of a systemic nature. From this the assumption was developed that systemic approaches are needed to provide helpful feedback and assistance for questions that diversity management practitioners have. It is also assumed that the application of Systemic Constellation increases the systemic competencies (see Table 3) of practitioners, which will improve diversity management practice (see Figure 1). 


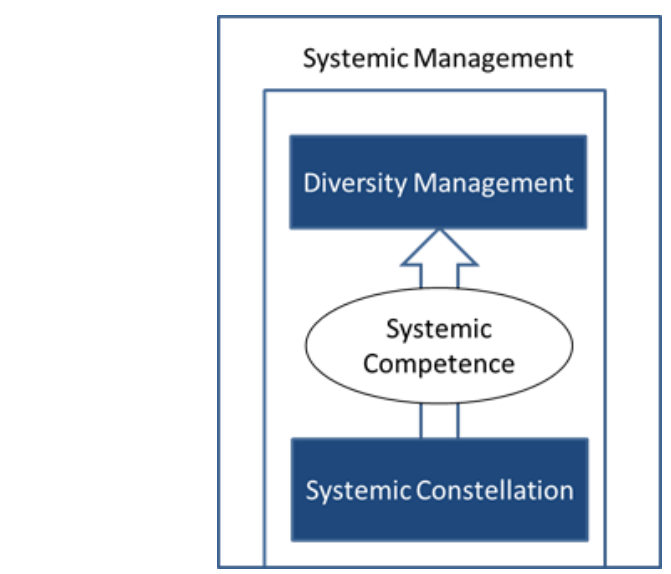

Figure 1: Application of Systemic Constellation in Diversity Management

For the purpose of this article, two exemplary themes out of the gender diversity field are chosen to study the contribution that Systemic Constellation provides for diversity management in general. These themes are of interest to both authors as they are part of the gender diversity management in a German university. Core aspects of the systemic framework will be looked at (for more information about systemic frameworks, see also Cao, Clarke, and Lehaney 2003) with the focus on Systemic Constellation as one method within systemic management (for more information about systemic management, see Schwaninger 2008; Hester and Adams 2014; Boos and Mitterer 2014).

\section{Research Initiative Application of Systemic Constellation}

This preliminary study is part of a broader research initiative at Reutlingen University looking at the application of Systemic Constellation in diversity management. Within this article Systemic Constellation is looked at from a German systemic perspective. In Germany there is currently a broad discussion about this method and its application in business, management, education, and research. From this background the following research questions emerged: Can diversity management benefit from the application of Systemic Constellation? If yes, how can it be applied in practice, and is it a "tool" for diversity management practitioners? What can be learned by the application of Systemic Constellation for further research into diversity management? (See Figure 2)

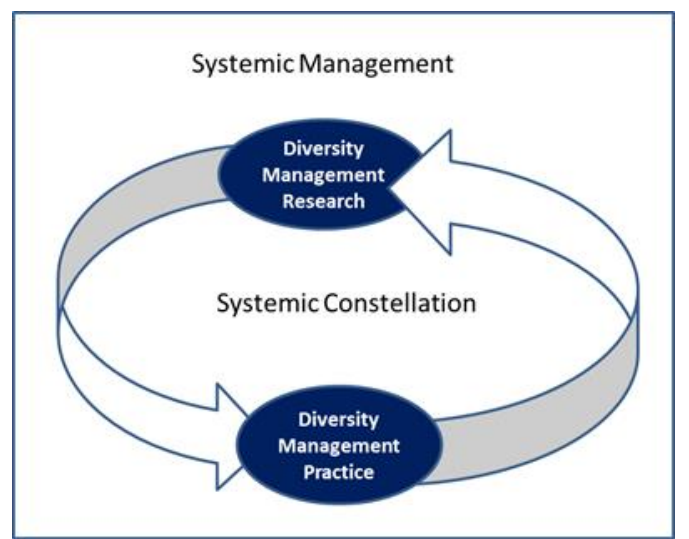

Figure 2: Systemic Constellation for Diversity Management Research and Practice 
Diversity management is discussed from a person-oriented focus, i.e., people involved in institutional diversity management and persons affected by their specific diversity factors in a specific environment (e.g., women in typical German industrial companies). Therefore, the research is part of the qualitative social science with a focus on applied research with a pragmatic research approach (see Creswell 2003). As Rossman and Wilson point out, "instead of methods being important, the problem is most important, and researchers use all approaches to understand the problem" (Rossman and Wilson 1985, taken from Creswell 2003, 11). Within the Systemic Constellation the focus is on a relational perspective (for more information about the relational perspective in research, see Bradbury and Lichtenstein 2000; Syed and Özbilgin 2009).

In contrast to traditional research approaches that focus on independent, discrete entities, methodologies oriented to relational concerns in organizations allow researchers to study the intersubjective and interdependent nature of organizational life. S/he thereby places more attention on the "space between," the space between subject and object, subject and research, researcher and subject, and the flexibility of the research process itself (Bradbury and Lichtenstein 2000).

With the pragmatic knowledge approach this article will contribute toward applicable research rather than theory building. According to Patton $(2002,217)$, researchers work on human and societal problems "to contribute knowledge that will help people understand the nature of a problem in order to intervene, thereby allowing human beings to more effectively control their environment." As Creswell $(2003,12)$ puts it, "truth is what works at the time; it is not based in a strict dualism between the mind and a reality completely independent of the mind."

\section{Preliminary Study}

Illustrated by two exemplary prototypical cases (based on real cases being abstracted) the application of Systemic Constellation in gender diversity is tested with the view to extend it to other areas as well. Using prototypical cases enables the user to abstract from concrete persons to a group of persons with similar issues under similar conditions (systemic problem). Combined with the initial idea to find new solutions with Systemic Constellation in diversity related issues, the initial hypotheses guiding this study are:

1) Gender diversity issues are being experienced individually but are inherently of a systemic nature, therefore the application of systemic models and methods is needed in order to improve the situation.

2) Systemic Constellation provides new insights and ideas for action for a specific gender diversity management challenge that cannot be realized through the use of other methods.

3) The performance of Systemic Constellation increases the systemic competencies of the participants and their solution results.

The first illustrated prototypical case has an institutional diversity management focus. It deals with the question of how institutions can enforce a women quota in management. The chosen perspective is the one of a diversity manager named Julia. The second case deals with the question of the medium- and long-term consequences for a professional career in contrast to a work-life balance especially for women in management positions (case study: Anna and her wish to reconcile her career with a family life). For each of the above mentioned topics a constellation workshop in different settings (participants, locations) was conducted. The aim was to evaluate how Systemic Constellation works under different settings and the value for the participants. This article presents the process and outcomes of these workshops. 


\section{Systemic Constellation}

Over the last thirty years Systemic Constellation, a method within the systemic approaches, has spread from the therapy field into a number of different areas, such as organization, management, and consulting. The systemic approaches have three common characteristics: 1) They take a holistic view on a system, its elements, and dynamics; 2) They believe that relationships are important; and 3) They acknowledge the constructive and contextual perspective of reality (see for example Ruegg-Stürm 2000; Lueger 2006; Bergmann and Daub 2006; Schwaninger 2008; Simon 2004, 2009, 2011; Boos and Mitterer 2014; Heinrich 2014; Levold and Wirsching 2012). In Systemic Constellation the singular system elements are not at the center of analysis but their relationships to each other. The relations determine the structure of the system. This does not only apply to relationships between individuals but also to relations between abstract elements and persons. By means of observations and interaction, new answers, findings, and insights can be gained (see Syed and Özbilgin 2009; Tatli and Özbilgin 2009; Mazur 2012).

\section{Core Characteristics}

Systemic Constellation uses the spatial presentation of a relationship within a system. For instance, this could be through one person (client) positioning other persons in the room as representatives of systems elements. This way the relationships are visualized through the distance between the persons and their respective viewing directions. The positioning of the system elements is a result of the client's feelings and thoughts, thus the inner picture of the client is projected. The positioning of the system elements in relation to each other is of major importance. By changing the positions and other interventions, the perception of the representatives can be altered on a physical, mental, and/or emotional level. Sparrer and Varga von Kibéd $(2010,197)$ call the constellation field, the sum of all representatives and their position, a "sensory organ." Human beings are able to perceive the quality of a specific spatial structure of people or symbols and can articulate the differences experienced. These articulated representative's perceptions or systemic resonances provide useful hints about the quality of a person's connection to other representatives. This ability is also called the "transverbal language" (Varga von Kibéd and Sparrer 2011, 234). By using Systemic Constellation, clients receive valuable impulses and ideas related to their specific issue. Through interventions such as repositioning of representatives, process work, tests, and trial runs, the constellation filed can be changed and new ideas to improve the issue at question can be experienced (Sparrer 2009a; Varga von Kibéd and Sparrer 2011).

Systemic Constellation often leaves the participants with the impression that systemic information can be gathered in a relatively fast and simple way compared to other qualitative or quantitative research methods. Participants experience the dynamics in systems and gain ideas about the different perspectives due to the so-called "representative perception" (Levold and Wirsching 2012, 237-38). Schlötter (2005) shows that the representative perception is a supraindividual experience and not just a product of chance. Clients can observe from a distance what is happening within the constellation field, which is perceived as an emotional relief. If necessary they can step into the constellation when a solution image is reached. This way the idea of a solution is conveyed to the client by all sensory channels, thus enabling a change of the inner picture that in turn facilitates changes in the outside world. This effect is proven by the "Heidelberger Study" through randomized, controlled trials in Family Constellation seminars (Hunger et al. 2014; Hunger et al. 2015, Weinhold et al. 2014).

\section{Different Types of Systemic Constellation}

Different types of Systemic Constellation methods are used depending on the intended purpose. Organizational and family constellations are often used to solve issues that individuals have. 
Generic and field constellations are used to discover (general) patterns and options. Relevant for this article are the organizational and generic types of Systemic Constellation (see Figure 3).

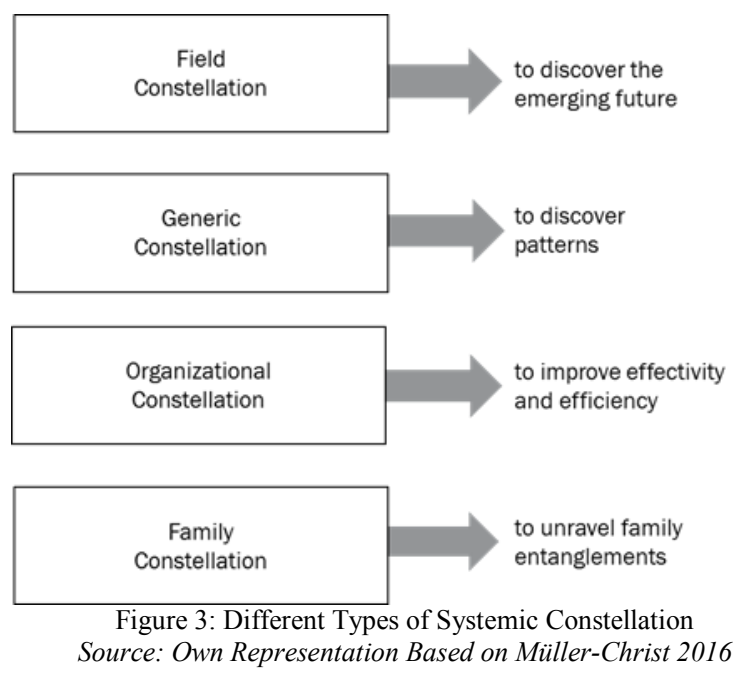

Systemic Constellation allows for "hidden work." Within hidden work the representatives are not named or told what or who they represent nor the topic and context (Sparrer 2007). Prototypical constellations, a form of generic constellations, are used in action-oriented research to discover patterns. The shifting between specific and generic constellations provides a particularly interesting approach, which might also have potential for use in diversity management (for information about specific and prototypical Systemic Constellation, see Vorhemus 2015b).

The applications of Systemic Constellation are examined in countless publications. The database of the German Association for Systemic Constellation lists more than 2,000 publications on the topic of constellations (Deutsche Gesellschaft für Systemaufstellungen 2016). The Carl-Auer publishing house currently offers fifty-nine books on Systemic Constellation (Carl-Auer Verlag 2016). There are more than fourteen studies that provide empirical evidence for the effectiveness of Systemic Constellation used in an organizational context (for the results of a critical review of fourteen studies about constellations in organization, see Weinhold et al. 2014).

\section{Diversity Management: A Systemic View}

The following description is based on a systemic-constructivist viewpoint. One person might experience issues as very problematic, but for another it is just an "ordinary task" that comes with everyday life. Wittgenstein $(2015,109)$ postulates that the "world of the happy man is a different one from that of the unhappy man." The cases used are exemplary and are taken from the German gender diversity management context. No claims to objectivity and completeness are given.

\section{Relationships in the Spotlight}

In diversity management, "diversity" describes a person's singular attributes or a combination of different characteristics (e.g., gender, age, descent, ethnicity, mental/physical capabilities) that can be seen and addressed as a problem or as an opportunity (Krell 2014; Schulz 2009; Vedder 2009). For the purpose of this article, diversity self-management is defined as a person's ability 
to successfully handle diversity challenges in a specific context. The handling will be seen as "successful" if situations that were previously perceived as stressful have improved.

As outlined above there are a number of players within the field of diversity. On the one hand there is the professional who has to ensure equality and push through corporate diversity goals. On the other hand there is the individual with his or her own diversity challenges. This article will introduce the model of Systemic Constellation as a tool for identifying underlying issues that hinder the process of achieving desired results whether these are on an individual or professional basis. When change processes stagnate and do not bring the desired results, the repertoire of processes, methods, and tools used is often extended and, if necessary, supported by internal or external certification (Wentling 2004). However, the actors, their relationship to other elements of the system, and their internal processes often remain unconsidered.

In Germany women have been in the spotlight of diversity management in the past few years, especially women working in fields where they are underrepresented, such as leadership positions, professorships, or STEM (science, technology, engineering, and mathematics) careers (see Süß and Kleiner 2008; Köppel 2014; Langholz 2014).

In this article diversity management will be discussed from two perspectives: the perspective of people who are involved in diversity management as part of their job and those that are affected by diversity issues themselves.

From an institutional perspective, diversity managers play the most significant role but "research on diversity practitioners suffers from a general lack of interest [...], despite these actors' role in design, implementation and monitoring of diversity policies and programs" (Tatli 2011, 239). Actors are officials in public and private organizations who are involved in the specific interests of singular or multiple groups of people within the organization. The questions arise: Who takes responsibility for the diversity management and implements it? Who supports the person in charge? How is the collaboration of the responsible and the supporting persons managed? This relationship is not well researched, just like the relationship between the diversity managers and the groups of people who they represent.

\section{Two Case Studies}

\section{First Example: Julia the Diversity Manager Having to Enforce a Women's Quota}

The first example, Julia and her difficulties with establishing a women's quota in her company, describes a typical problem that can be encountered in gender diversity management from an institutional perspective. A management board member of a typical German company possesses the following traits: male, German, fifty-three years of age, Caucasian, has no migration background, is heterosexual, married with children, and has no physical or mental disabilities (Buchhorn 2014). Women and other minorities are underrepresented in this monoculture hierarchy.

The management of staff diversity is often part of the human resources department and has little priority. As such, it is rarely handled by specialists (see Süß 2010). Köppel (2014) describes a rather hesitant formation of diversity management structures in Germany's top thirty DAX companies. In 2010, sixteen of thirty DAX companies employed a diversity manager. In 2011, the number climbed to twenty-three and in 2012 to twenty-five. In 2013, the upward trend seemed to have ceased and only twenty-two companies could name a contact person for diversity issues. In 2014, the number of diversity managers increased by three. So, on the one hand, the formation of diversity management structures seems to have consolidated. On the other hand the status quo of 2012 could not be surpassed. It seems that diversity management cannot be spread any further (see Köppel 2014). Plett (2006) describes it as extraordinary how much fear and animosity the topic of diversity management evokes. The motives for implementing diversity management in a company can be varied. They range from conforming to legal obligations such 
as the General Equal Treatment Act in Germany to wanting to transform the company into a multicultural organization (see Allgemeines Gleichbehandlungsgesetz 2016; Cox 1994; Süß 2010; Weinert 2012; Deloitte 2013; Köppel 2014).

Julia has been working as the diversity manager of a large German mechanical engineering company for the past three years. Three years ago it was decided, in the context of a discussion about a higher participation of women in leadership positions, to raise the percentage of women on the first- and second-management level by 5 percent every year until 30 percent is reached. The achievement of this goal is connected to the variable annual bonus of the diversity manager, the head of human resources, and the responsible managers on the respective company levels. The results of the past three years are sobering. The percentage of women in leadership positions could not be raised in spite of considerable activities and measures that were taken. Both sides offer a multitude of reasons. Julia wonders what kind of obstacles stand in the way of implementing the change. Technical errors with regard to the design and implementation of the control system could not be found. Comparisons with other companies show that other companies also experience difficulties filling leadership positions with women. Since Julia's wage development and her professional advancement depend on the achievement of this target, the pressure to succeed is high. Julia is trying to work out what kind of steps should be taken next. It appears that conventional approaches that are taught in traditional management classes (such as focusing on tools, setting targets, planning measures, and offering incentives) are of limited use when trying to deal with problematic situations in diversity management (see Wentling 2004; Shore et al. 2009; Gonzalez 2010; Riccò and Guerci 2014).

\section{Second Example: Anna and Her Wish to Reconcile Her Career with a Family Life}

The second case describes typical problems in the field of gender diversity from the perspective of the affected person. It deals with Anna and her wish to reconcile her career with a family life. Up until the age of thirty, women hold leadership positions as often as men do. For those who are thirty and older, the gap between their career life and time for family obligations keeps growing larger (Hammermann, Schmidt, and Stettes 2015). Couples with an emancipated family model who demand a reconciliation of career and family life need support from their families and/or their companies. Only 46 percent of the female respondents across nineteen countries believe that having children will not damage their career advancement (see Thomson Reuters Foundation et al. 2015). In the United States, only 60 percent of highly successful women get married compared to 83 percent of highly successful men. Forty-nine percent of highly successful women remain childless while only 19 percent of highly successful men do not have children (see Hewlett 2002).

Furthermore, it can be observed that women are faced with discriminations that slow down or prevent further career development (glass ceiling) or bring inexplicable differences in income (wage gap). A study by Ullrich, Pluut, and Büttgen (2015) shows that in dual-income couples it is usually the women who sacrifice the career ambitions for the family (for example, if the husband is relocated to a business location abroad). The long-term consequences for women and their families after their return to working life have not been researched (see Ullrich, Pluut, and Büttgen 2015). In Germany, studies have shown that women take care of the majority of family duties even if they are employed full time. They find it difficult to fulfil the time requirements of career positions (see Hammermann, Schmidt, and Stettes 2015; Thomson Reuters Foundation et al. 2015). This means that organizational measures can be helpful but might not necessarily solve all problems regarding the balancing of work and family life.

Anna's story represents one of the most typical gender diversity problems of career women that are also illustrated in many other case studies (see Von Taube 2015). Anna is a careerminded woman, twenty-eight years old, holds an excellent master's degree in business administration, attended a famous international business school, and has already four years of 
work experience as a product manager in an international mechanical engineering company. For her current job and corresponding career opportunities, she moved to Frankfurt where she has not yet managed to establish a new circle of friends due to her long working hours. She still has contact to some old fellow students who are now young professionals and find themselves in similar situations. Anna wants to have an emancipated relationship, go ahead in her career, and be financially independent. She also intends to have children. She wonders how she can succeed with all of these things at the same time. Especially her wish to have children poses a challenge. In her mind, her work schedule can already hardly be reconciled with her private interests. Her limited leisure time is spent on day-to-day things such as housekeeping or sports and maintaining her social relationships. If Anna decides that she wants to go ahead with her plan to have children, she will start to feel even more pressed for time and experience the "rush hour of life."

\section{Conceptual Models for Diversity Management and Systemic Constellation}

The two case examples depict typical gender issues in different contexts. One person might experience an issue as very problematic; for another it's just an "ordinary task" that comes with everyday life. Thus, it can be helpful to deconstruct the construct of reality that is perceived as problematic and find a more helpful, resourceful way of dealing with it. Otherwise the person might believe that the described problems are his or her own fault or caused by adverse circumstances that cannot be changed. The resulting feeling of powerlessness can lead to burnout, withdrawal from leading positions, etc.

The authors believe that blaming problems on oneself is only of little help. These problems, according to the authors' theory, result from systemic causes, meaning they are a result of certain constellations, not of "deficits in character." One working hypothesis that should be discussed is the following: Gender diversity problems are experienced individually but are inherently systemic in nature. Furthermore, the authors believe that systemic-constructivist approaches have the potential to improve complex, problematic situations. Persons and their relationships within the relevant systems and systemic environments have to be included when a problem is being considered. The two cases provide examples of how Systemic Constellation can be applied. Systemic-constructivist models have the three following characteristics:

1. Incorporating context and differentiating between structural levels (macro-/meso/micro-level): Overarching influences and development tendencies in diversity management can significantly influence thoughts, actions, and experiences on subsequent levels. The patterns or effects cannot be easily identified. Singular problems can be examined within a larger context (see Syed and Özbilgin 2009; Gonzalez 2010; Tatli 2011; Pringle and Ryan 2015).

2. Generic and specific system elements: Depending on the particular problem and specific case, different system elements may be relevant. In principle, system elements can be individuals, groups of people, or abstract elements such as a specific goal, a career path, or a task. In generic models, abstract structural elements such as a person's career path or their family can be used. In specific system, these elements can be further differentiated by adding concrete content. For example, the elements father, mother, child 1 , and child 2 can be chosen to describe "family." Individual models can be very diverse, depending on which system elements are seen as relevant and brought into focus (constructivism).

3. Relational approach: Singular system elements will not be the center of analysis. Instead, their relationships to each other determine the structure of the system and are of utmost importance. This does not just apply to relationships between individuals but also to relations between abstract elements and persons. By means 
of these observations, new answers, findings, and insights can be gained (see Syed and Özbilgin 2009; Tatli and Özbilgin 2009; Mazur 2012).

\section{Example for a Conceptual Model for Achieving Goals in Gender Equality}

Julia has already learned that she cannot reach her goal of increasing the number of women in leading positions within her company by using traditional methods such as setting target values, providing a budget, or starting a communication campaign. The interests of the persons involved are too heterogeneous. The question arises of how the different elements, the organizational system, the goal system, and diversity management are related to each other under the specific context of the organization. This can be analyzed with common instruments, for example questionnaires, or using the Systemic Constellation method.

Figure 4 shows a generic systemic model of achieving goals in gender equality. It can be seen how the macro-level (Germany with its legal and political system) encompasses the mesolevel, the company with its goal of women's quota, the organization, and in this case the diversity management. The individuals in question are part of the system through their position within the company and on a micro-level through their own economic (reward) system. As all of these elements influence the overall situation, they need to be considered when researching options of action.

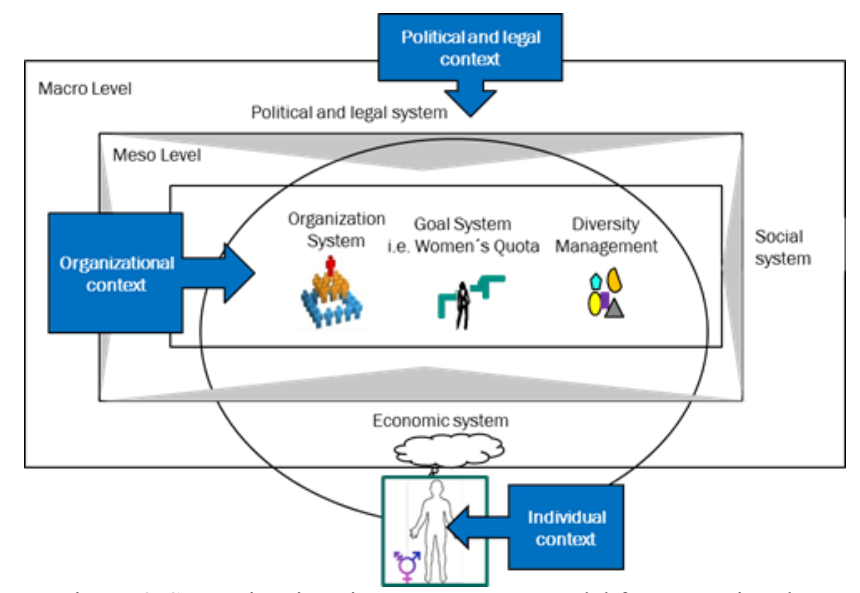

Figure 4: Systemic Diversity Management Model for Increasing the Proportion of Women in Management Positions

In order to set up a specific constellation, all core elements of the issue need to be identified, for instance the organizational system, top-management, female/male managers, and female/male management trainees. The facilitator of Systemic Constellation workshops has hereby a crucial role as all influential elements need to be identified out of a wide range of visible and invisible elements (Müller-Christ 2016).

\section{Example of a Conceptual Model for the Reconcilability of Work and Family Life}

Anna's individual challenge of how she can reconcile her career while building a family requires a look at her workplace, her family system, and the relevant context factors under the prevailing circumstances. It makes a difference for Anna whether she seeks to build a career and a family in Germany, Greece, or Sweden. The conditions that influence the reconcilability of career ambitions and family planning do not only differ between countries (macro-level) but also between regions (for example, rural or urban). They also depend on whether someone is working at a university or for a company (meso-level). Circumstances and conditions can be very 
heterogeneous. Furthermore, political, legal, and economic changes (such as the implementation of a women's quota or the legal right to child care) can have a larger or much smaller influence on an individual's situation than actions within the person's immediate environment (microlevel).

Often, the issue of balancing work and family life is seen as a task for the employing organization, which includes for example providing different options for child care. In Germany, both the government and many companies have taken steps to improve the reconciliation of work and family life in the past few years. For example, child care facilities have been built, parental leave is provided, and there are options for part-time work or flexible working hours. For many women and their families, this is a vast improvement. For others, however, these measures are insufficient. Below, one way of building a model that includes both the organizational and the private sphere is illustrated:

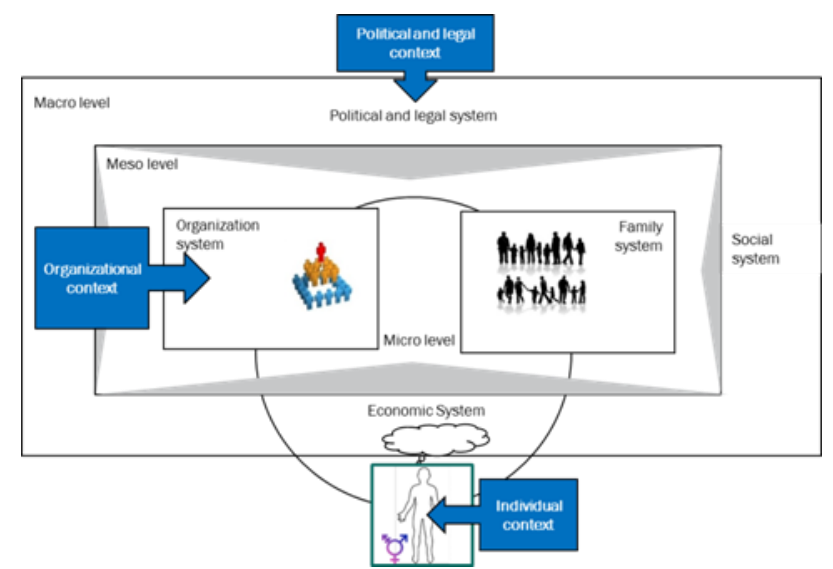

Figure 5: Systemic Model for the Reconciliation of Work and Family Life

The perceived relief of organizational measures depends on factors in the family system and on individual aspects. In Anna's example, interdependencies between her situation at work, her current family life (for example, the participation of her partner), and her personal situation (such as her physical, emotional, intellectual, and financial resources) can be observed. A high level of stress in one of these systems (such as parents in need of care or being a single mother) can reduce the relieving effect of having child care options. A change in the family system (such as grandparents who lend a hand or receiving money to hire a nanny) can have a more significant effect on the whole situation than isolated actions of the company.

The model shown in Figure 5 can be used for the analysis and description of the initial situation and the implementation of change. For Anna, the generic organization system, the family system, the area of conflict between both of these systems, and legal, economic, or social factors can be relevant elements. This causes a shift in discussion and it focuses on the question of how a balance between work and family life can be reached through self-management between those two fields. Depending on the individual's description of the situation, additional elements can be identified and included, such as the person's partner, child/children, or other family members. Within the organization system, the collaboration with superiors and/or team members can be important. The circle in Figure 5 symbolizes how the individual is connected to the organization system and the family system.

\section{Demonstration of the Constellation Processes}

In the following section the constellation process is introduced and illustrated for each of the two cases. 


\section{First Example: Julia the Diversity Manager Enforcing a Women's Quota}

Julia's example of trying to achieve a women's quota in management will be used to illustrate the individual stages of a Systemic Constellation process (see Figure 6) and the results of each phase will be explained. This constellation was re-created during an interactive workshop at the Fifteenth International Conference on Diversity in Organizations, Communities \& Nations in Hong Kong in 2015.

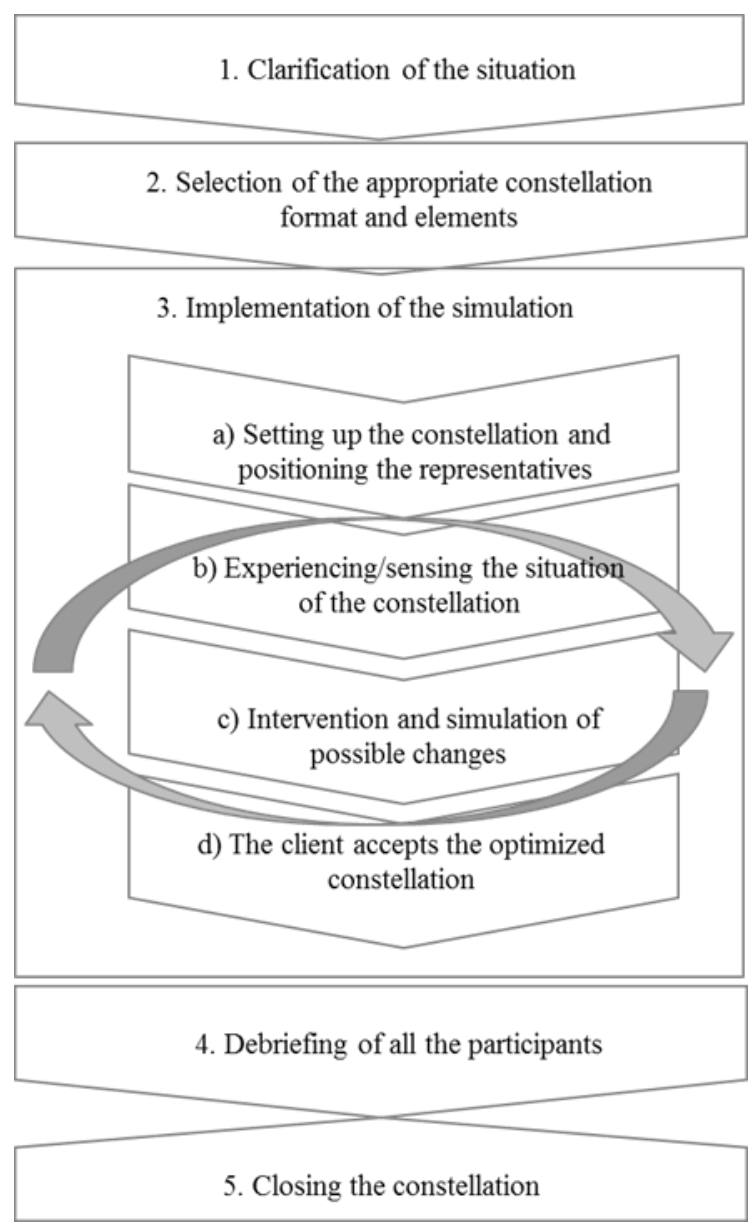

Figure 6: Specific Constellation Process

Source: Own Representation Based on Sparrer 2009a, 9-17

\section{Clarification of the Situation}

In an interview, the client and the host (facilitator) discussed the situation. In this case, the question of why the percentage of women could not be raised was examined. The previous activities were also discussed. At this stage, the facilitator and the client agreed what results would constitute a successful constellation.

Julia said she would describe the constellation process as successful if she subsequently had an idea of how she could handle the topic in the future. She added that it would be great if she could feel being relieved of a weight and be more confident afterwards. She would also like to gain a better view on the internal barriers and obstacles within the system. The success of the 
constellation work will be judged after the closing of the constellation by comparing the outcome to the above mentioned points.

\section{Selection of the Appropriate Constellation Format and Elements}

In this case, the format of an organizational constellation was chosen (see Vorhemus 2015c). An important task of the facilitator is the identification of the relevant system elements from the perspective of the client. Additional elements can be added in the course of the constellation process if necessary. In this case, the following persons and groups were chosen: the chief executive officer (CEO), the diversity manager, the group of potential female leaders, the group of responsible line managers, the women's male managing colleagues, the target of 30 percent women in top management (abstract element), and the objective of the organization (abstract element).

\section{Implementation of the Simulation}

For each element and also for herself (focus), Julia chose a representative from the participants of the workshop. They received the following instructions: The constellation is not a role-play; they must remember physical, emotional, or mental sensations, which they might have had while being positioned, during later changes in position and be able to describe them; they cannot act independently; and they have to follow the facilitator's instructions. Additionally, the representatives are advised that their representation relates to the view of the client and does not allow for conclusions about the respective people in general.

\section{3a. Setting up the Constellation and Positioning the Representatives}

The client moved the representatives into the constellation field and to their "place" by touching them on their shoulder blades.

\section{3b. Recognizing the Situation of the Constellation}

In a second step, the host asked the representatives if they noticed a change in sensation (emotional, physical, or mental) on their way into the constellation field or right now in their current position. The answers provided valuable insights about the evolution of the issue and the current situation from the client's perspective. It reflected her inner thoughts and feelings on the matter. In this case, the representatives made the following statements after an inquiry about the initial positioning (excerpt):

Table 1: Selected Statements of the Representatives

\begin{tabular}{|l|}
\hline 1. CEO \\
* does not feel responsible for the target \\
* has a certain distance to everyone, looks out of the window \\
* feels very powerful and successful \\
("the real business issues are turnover, profit, etc.") \\
\hline 2. Diversity manager \\
* is isolated and feels a little bit frustrated \\
* feels that she is working very hard \\
* looks outside the constellation field \\
* no contact to the responsible managers \\
3. Group of high-potential women \\
* no contact with the target \\
* do not want to be a "Quota Woman" (fulfill a certain women's quota) \\
* stand at a distance to the male colleagues, are turned away from them \\
* do not support the diversity manager
\end{tabular}




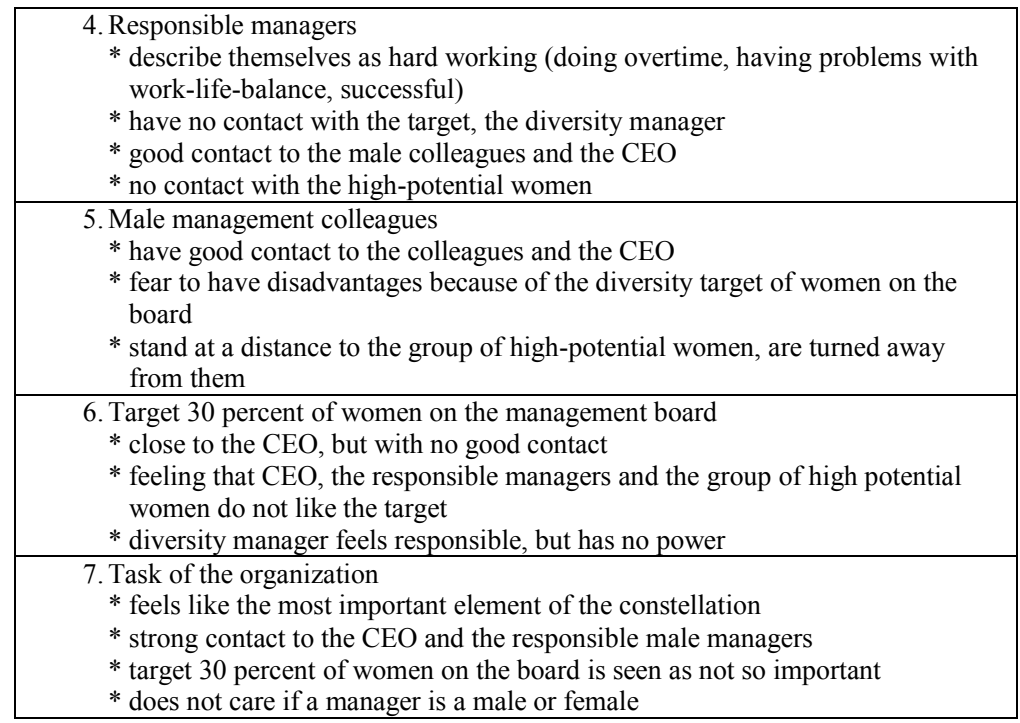

The host asked Julia if the representatives' statements reflect her situation. Julia is surprised how well these statements coincided with her inner feelings and thoughts of the situation.

\section{3c. Intervention and Simulation of Possible Changes}

At this point in the process, there are a number of options for how to proceed. In this case, the client wanted to learn more about the dynamics within the system. Therefore, the representatives were asked to slowly follow their impulses to move and to make sure that their movements happened one after another and not at the same time. These movements led to a new constellation image. Afterwards, the host once again asked the representatives if they noted any changes in feelings (intellectually, physically, and mentally). The turning of the CEO was an essential change in this case. His initial focus on the outside was altered by his repositioning and he now had a view of the events from within as well as from the outside (see Figure 7).

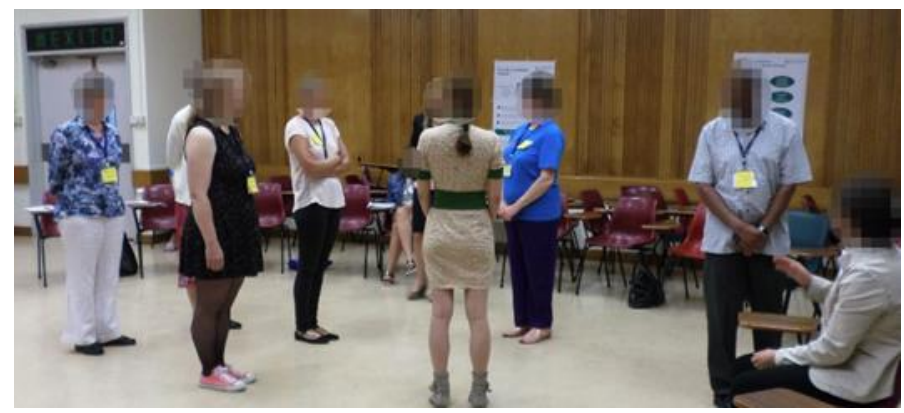

Figure 7: Turning of the CEO as an Impulse of Motion

The CEO noted that he was finding it difficult to look inside since he felt that it was his duty to look out for the company's competitors, to keep the company in the game, and to look ahead.

The movement of the diversity manager was another important change. She moved from a central positon to a position at the edge of the field where she could see all other elements. This shift caused relief in all of the representatives and within her. Since the second image constituted a vast improvement, the constellation was ended there. The next step (3d) was skipped. This step is usually taken so the client can step into the position of her representative and experience the 
new situation with all her senses. This way, the new constellation can be internalized by the client.

\section{Debriefing of the Participants}

The debriefing procedure is determined by a dialogue between the host and the client. First the client is asked whether she was able to reach her initial goal. Then, depending on the situation, a discussion about how the findings can be transferred into work-life follows. Julia describes the process as very beneficial and relieving, and that she now hopes to enter into a better dialogue with the CEO. She has also realized that an internal step aside can help the situation and that she wanted to give this new position a try. She has gained valuable insights into her relationships to the individual groups and their interests and believes there is a chance to alter the relationships. The representatives reported that they experienced the constellation as very harmonious and intense and that the change in their positions had a very positive influence on how they felt in their representation.

\section{Closing the Constellation}

Part of closing the constellation is taking the representatives out of their representation to make sure that no unknown aspects are transferred into a representative's own life. Depending on the context, the results of the constellation work can be documented so the change process can be retraced at a later time. This is important to further develop a person's systemic skill set.

\section{Second Example: Anna and Her Wish to Reconcile Her Career with a Family Life}

The second example tells the story of Anna and her wish to reconcile her career with family life. This situation shall be outlined based on the systemic model depicted in Figure 8.

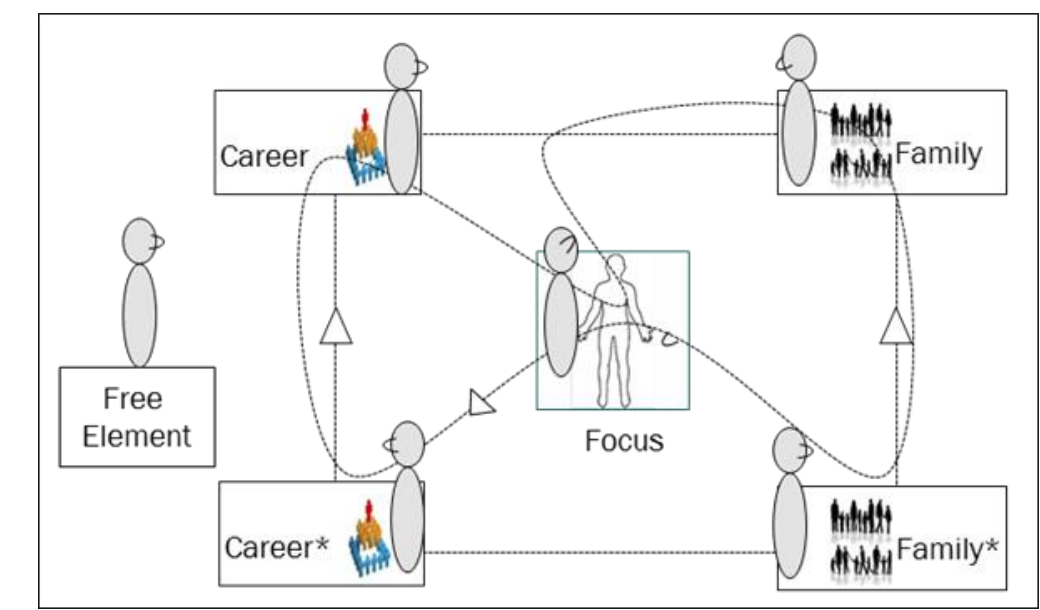

Figure 8: Prototypical Value Quadrant Constellation of Reconciliation of Work and Family Life Note: Career/Family* Means an Exaggeration of Career/Family Life

To obtain a better understanding of the issue of "reconciliation of work and family life," a generic Systemic Constellation approach was chosen. An individual constellation is done for one particular person with a personal issue. A generic constellation can be understood as a prototype, which can be used as stand-alone method for generalization purposes or in combination with individual, specific applications. If a generic constellation is used without a specific focus of 
attention, it might be possible to discover generic interrelations for scientific purposes (MüllerChrist 2016).

In this Systemic Constellation the value quadrant model of Varga von Kibéd (2015) (see Varga von Kibéd 2015; Schulz von Thun 2015a, 2015b) was used, whereby two seemingly opposing positions are put into opposition with their exaggerated version. The prototypical application of the value quadrant, relating to the topic of reconciling work and family life, used in the workshop looked like this:

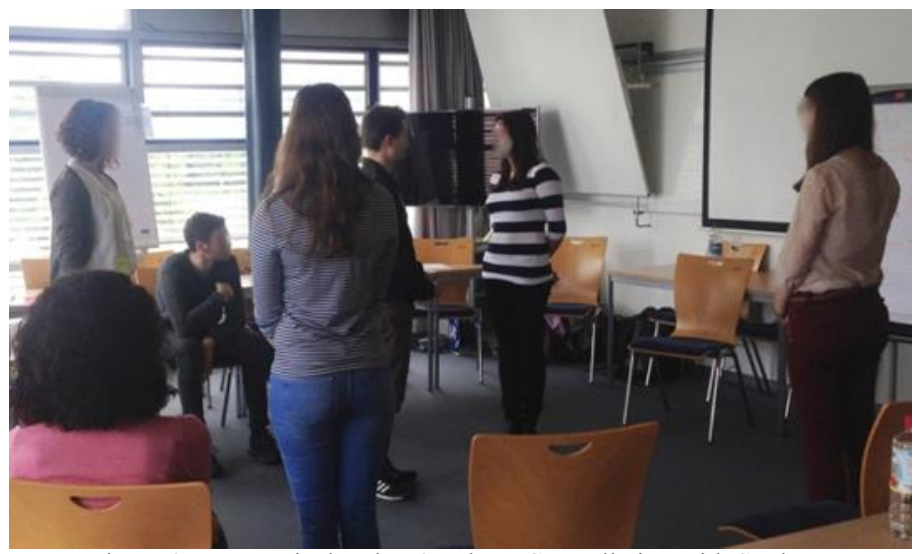

Figure 9: Prototypical Value Quadrant Constellation with Students

Relating to the Topic of Reconciling Work and Family Life

The representatives are positioned in order to set up a value quadrant (see Figure 8). It contains the person's career and family as well as the exaggeration career and exaggeration family. In the case of family the exaggerated version could represent 100 percent availability for the family as, for instance, a full-time housewife. The exaggerated version career overemphasizes the career and totally neglects the family. The free element symbolizes wisdom. Outside the constellation field, representatives of the parents or other contextual factors can be named and added if necessary. The workshop was conducted in a master's lecture at Reutlingen University.

Table 2: Selected Statements of the

Representatives during the Prototyping Constellation

\begin{tabular}{l} 
1. Anna \\
* looks with one eye at career but also tries to look at family \\
* she feels as if "I take something away from the family" \\
* she would like "to have an even bigger eye on family" \\
* she feels the social expectation from the environment around her \\
* feels more comfortable to move toward family \\
\hline 2. Family \\
* has not the feeling that there is an equilibrium in the constellation \\
"overemphasis of the career" \\
* feels a little bit neglected but important for the future \\
3. Overemphasis of family (family*) \\
if the prototypical focus is looking at the family, it gains \\
4. Overemphasis of career (career*) \\
* would like to have the complete attention of the focus \\
* feels very strong and important \\
* is in inner competition with family
\end{tabular}




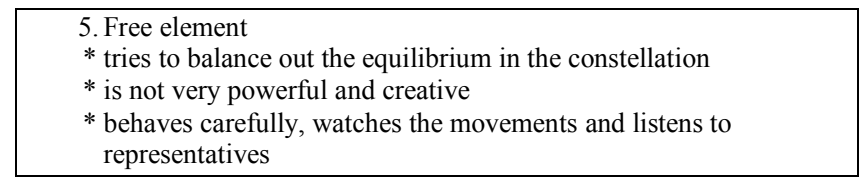

In this Systemic Constellation the issue was of a generic nature, i.e., not based on an individual request. All students will at some stage encounter similar issues in their lives; therefore, it was of interest to all participants. In this case the outcome was used for a discussion within the group of students. Enclosed are some of the statements of the participants when discussing the results:

"The biggest learning experience was for me to feel to be a part of the situation. It was very interesting to set up the situation of reconciling career and family and be part of it. It has changed my perception of the topic."

"It was an extraordinary experience to represent the exaggeration of career. I had a powerful feeling to captivate the focus. When he moved towards the family I experienced feelings of loss."

"I have gained ideas about what this topic is all about. I would really love to do a constellation with my partner in order to get ideas for the future."

In order to evaluate the subjective learning progress by using Systemic Constellation, the participants were asked to rate the experience $(1=$ Very Good to $5=$ Satisfactory $)$ :

Table 3: Evaluation of the Systemic Constellation Workshop

\begin{tabular}{|l|c|}
\hline Experience of the representative perception & 1.4 \\
\hline Insight in the transverbal language & 1.8 \\
\hline Understanding of the systemic principles & 2.3 \\
\hline Recognizing the dynamics in social systems & 1.8 \\
\hline Ideas of possible interventions & 1.8 \\
\hline Increasing of the systemic competence & 1.7 \\
\hline Average rate & 1.8 \\
\hline
\end{tabular}

As can be seen in the marks as well as the individual statements, the participants rated the outcome as very good. New insights were gained and also new action alternatives like including the partner and conducting specific constellations came up.

\section{Summary of the Key Findings}

In this article the basics of Systemic Constellation were explained. The case studies used illustrated the application of Systemic Constellation for diversity management issues. In these two cases small setups were used with little interventions. Even small changes such as setting up the first picture and asking the representatives about their differences in perception resulted in very helpful insights. Each of the Systemic Constellation workshops performed was highly valued by the participants, whether they were the focus, representatives, or just observers. Within a short period of time all participants experienced the representative perception.

At first glance it looks fairly easy to perform a Systemic Constellation workshop but in reality it is a complex and demanding task requiring experience and training especially in identifying the right elements to include. Therefore, a precondition for conducting a Systemic Constellation workshop is to have a qualified facilitator. It is advisable to look for a professional facilitator, who has a broad professional qualification in the methodology of Systemic Constellation, in diversity management and of a constructivist attitude. 
Systemic Constellation creates a deeper understanding of connections between people, tasks, targets, and many other possible elements. By using different options for intervention, improvements in the daily work can be achieved. Through painting a new picture, the client's existing inner picture can be changed. That way, new thoughts, actions, and behavior are made possible in the outside world, which increases the efficiency and effectiveness of individuals, work spaces, or whole organizations.

Other applications of Systemic Constellation could be situations where different perspectives are of interest (so-called bifocal constellations). A deeper appreciation of different viewpoints is not only relevant when gender differences come into play, but it also provides many options for solving conflicts in the area of politics and daily life. One other example could be to work with Systemic Constellation on ambiguities and fields of tensions within diversity management (e.g., on a political level between feminism and hostility toward women, uniformity, and diversity within management). Another interesting approach could be to discover the possibilities of this instrument to support the integration processes of the refugees in Germany.

The authors believe that Systemic Constellation as a holistic, relational approach is of significant help in solving diversity problems especially as institutional or individual diversity management issues are often hard to grasp (such as the glass ceiling phenomenon, inexplicable income differences, cases of burnout, mobbing or discrimination, the management of conflicting goals, or the discussion of the "right" degree of diversity). The researchers also see interesting possibilities to use Systemic Constellation as an additional teaching method for diversity management.

A challenge for the researchers was to find useful approaches to integrate Systemic Constellation into the existing research methodology of applied science. It has to be evaluated whether it might fit into the soft system methodology, or whether it is a part of a completely new research method (see Müller-Christ 2016), or whether it is just an evaluation tool. Furthermore, methods need to be developed that measure the effects of Systemic Constellation, which will also result in a better acceptance within the research community. For the time being the focus is on transcribing the interviews and finding good documentation methods.

Systemic Constellation helps actors, institution, or individuals, to find new aspects in old problems, ideas of how to improve situations and how to build bridges. Therefore, Systemic Constellation supplements the existing methodology toolboxes with an instrument focusing on relationships, providing a holistic approach.

\section{REFERENCES}

Allgemeines Gleichbehandlungsgesetzt 2016. "Juris. Bundesministerium der Justiz und für Verbraucherschutz." Allgemeines Gleichbehandlungsgesetz [General Equal Treatment Act]. Accessed June 24, 2016. http://www.gesetze-im-internet.de/agg.

Andresen, Sünne, Mechthild Koreuber, and Dorothea Lüdke, eds. 2009. Gender und Diversity: Albtraum oder Traumpaar? Interdisziplinärer Dialog zur "Modernisierung" von Geschlechter- und Gleichstellungspolitik [Gender and Diversity: Nightmare or Dream Couple? Interdisciplinary Dialog for the Modernization of Gender and Equality Policy]. SpringerLink: Wiesbaden: VS Verlag für Sozialwissenschaften.

Archibong, Uduak, Monica O’Mullane, Daniela Kállayová, Nazira Karodia, Caitríona Ní Laoire and Ilenia Picardi. 2016. "Guided Reflection as an Organisational Learning and Data Collection Tool in a Gender Equality Change Management Programme." The International Journal of Organizational Diversity 16 (1): 19-34. 
Bergmann, Gustav, and Jürgen Daub. 2006. Systemisches Innovations - und Kompetenzmanagement: Grundlagen - Prozesse - Perspektiven [Systemic Innovationand Competence Management: Basics - Processes - Perspectives]. Wiesbaden: Gabler.

Boos, Frank, and Gerald Mitterer. 2014. Einführung in das Systemische Management [Introduction to Systemic Management]. Heidelberg: Carl Auer.

Bradbury, Hilary, and Benyamin B. Lichtenstein. 2000. "Relationality in Organizational Research: Exploring the Space Between." Organization Science 11 (5): 551-64.

Buchhorn, Eva. 2014. Unternehmen "Deutsch, Männlich, 53 Jahre Alt" [Companies "German, Male, 53 Years Old"]. Manager Magazin, April 22. Accessed June 22, 2016. http://www.manager-magazin.de/unternehmen/karriere/a-965050.html.

Cao, G., S. Clarke, and B. Lehaney. 2003. "Diversity Management in Organizational Change: Towards a Systemic Framework.” Systems Research \& Behavioral Science 20 (3): 23142.

Carl-Auer Verlag. 2016. Systemaufstellungen [Systemic Constellation]. Accessed June 16, 2016. http://www.carl-auer.de/programm/thema/systemaufstellungen.

Cox, Taylor. 1994. Cultural Diversity in Organizations: Theory, Research, \& Practice. San Francisco, CA: Berrett-Koehler.

Creswell, John W. 2003. Research Design: Qualitative, Quantitative, and Mixed Method Approaches. 2nd ed. Thousand Oaks, CA: Sage Publications.

Deloitte. 2013. "Talent \& Diversity Management in Deutschen Unternehmen: Ausgewählte Studienergebnisse" [Talent \& Diversity Management in German Companies: Selected Study Results]. Accessed June 21, 2016. http://www2.deloitte.com/content/dam/Deloitte /de/Documents/human-capital/C-HCAS-Talent-Diversity-Studie-2013.pdf.

Deutsche Gesellschaft für Systemaufstellungen. 2016. Literatur zur Aufstellungsarbeit [Literature for Systemic Constellation]. Accessed June 21, 2016. http://www.familienaufstellung.org/listen/literatur/publikationen.php.

Gesmann-Nuissl, Dagmar, Ronald Hartz, and Marcus Dittrich, eds. 2014. Perspektiven der Wirtschaftswissenschaften [Perspectives of Economic Sciences]. Wiesbaden: Springer Fachmedien.

Gonzalez, Jorge A. 2010. "Diversity Change in Organizations: A Systemic, Multilevel, and Nonlinear Process." Journal of Applied Behavioral Science 46 (2): 197-219.

Hammermann, Andrea, Jörg Schmidt, and Oliver. Stettes. 2015. Familie und Karriere: "Beschäftigte zwischen Karriereambitionen und Familienorientierung. Eine empirische Analyse auf Basis der BIBB/BAuA-Erwerbstätigenbefragung 2012" [Family and Career: "Employees between Career Ambitions and Family Orientation. An Empirical Study Based on the BIBB/BAuA-Employee Survey 2012]. Institut der Deutschen Wirtschaft Köln [Institut of the German Economy Cologne]. Accessed June 22, 2016. http://www.iwkoeln.de/presse/pressemitteilungen/beitrag/familie-und-karriere-ein -entweder-oder-212025.

Heinrich, Harald. 2014. Systemisches Projektmanagement: Grundlagen, Umsetzung, Erfolgskriterien [Systemic Project Management: Basics, Implementation, Success Criteria]. Munich: Carl Hanser Verlag.

Hester, Patrick T., and Kevin M. Adams. 2014. "Systemic Thinking: Fundamentals for Understanding Problems and Messes." Topics in Safety, Risk, Reliability and Quality, volume 26. Heidelberg: Cham: Springer.

Hewlett, Sylvia A. 2002. "Executive Women and the Myth of Having It All." Harvard Business Review 80 (4): 66-73.

Hunger, Christina, Annette Bornhauser, Leoni Link, Jochen Schweitzer, and Jan Weinhold. 2014. "Improving Experience in Personal Social Systems through Family Constellation Seminars: Results of a Randomized Controlled Trial." Family Process 53 (2): 288-306. doi:10.1111/famp.12051. 
Hunger, Christina, Jan Weinhold, Annette Bornhäuser, Leoni Link, and Jochen Schweitzer. 2015. "Mid- and Long-Term Effects of Family Constellation Seminars in a General Population Sample: 8- and 12-Month Follow-Up." Family Process 54 (2): 344-58. doi:10.1111/famp.12102.

Köppel, P. 2014. Diversity Management in Deutschland. Benchmark 2014: Strategie oder Alibi? [Diversity Management in Germany. Benchmark 2014: Strategy or Alibi?]. Accessed May 28, 2016. http://www.synergyconsult.de/pdf/Benchmark_DM_14.pdf.

Krell, Gertraude. 2014. "Chancengleichheit für alle und auch als Wettbewerbsvorteil - Bilder von Diversity" ["Equal Opportunity for All and Also as Competitive Advantage Pictures of Diversity"]. In Perspektiven der Wirtschaftswissenschaften [Perspectives of the Economic Sciences], edited by Dagmar Gesmann-Nuissl, Ronald Hartz, and Marcus Dittrich, 17-35. Wiesbaden: Springer Fachmedien Wiesbaden.

Kupczyk, Teresa, Aneta Klaudia Szymanska, Joanna Kubicka, and Anna Oleszkiewicz. 2015. "Implementation of Diversity Management in Poland and Its Relationship with Organizational Trust." The International Journal of Organizational Diversity 15 (4): $17-27$.

Langholz, Marlene. 2014. "The Management of Diversity in U.S. and German Higher Education." Management Revue 25 (3): 207-26.

Levold, Tom, and Michael Wirsching, eds. 2012. Systemische Therapie und Beratung: Das große Lehrbuch [Systemic Therapy and Consulting: The Big Textbook]. Heidelberg, Neckar: Carl Auer.

Lueger, Günter, ed. 2006. Solution-Focused Management. Solution-Focused Management Series 1. Munich.

McConatha, Melina, and Nikki DiGregorio. 2016. "Supporting Diversity: Creating New Constructs of Families and Communities in the Virtual World." The International Journal of Diverse Identities 16 (1): 1-18.

Mazur, Barbara. 2012. "Diversity from the European Perspective." Journal of Intercultural Management 4 (4): 85-93.

Müller-Christ, Georg. 2013. "Konzepte in Beziehung Setzten: Systemaufstellungen in der Universitären Managementlehre und -Forschung" [Putting Concepts into Context: Systemic Constellation in University Managerial Teaching and Research]. Praxis der Systemaufstellung [Systemic Constellation Practice] 14 (1): 70-77.

2015. "Systemsiches Visualiseren, Strukturbilder und FoL-A-Lab: Über die Weiterentwicklung der Aufstellungsmethode im Kontext der universitären Managementforschung und -lehre" [Systemic Visualisation, Pattern Images, and FoL-ALab: About the Development of System Constellation in the Context of University Managerial Teaching and Research]. Praxis der Systemaufstellung [Systemic Constellation Practice].

2016. "Systemaufstellung als Instrument der Qualitativen Sozialforschung. Vier, Vielleicht Neue Unterscheidungen aus der Anwendungssicht der Wissenschaft" [Systemic Constellation as Instrument for Qualitative Social Science. Four, Perhaps New Distinctions for the Application in Science]. In Organisationsaufstellung [Organizational Constellation], edited by Gunthard Weber and Claude Rosselet. 2rd ed. Heidelberg: Carl Auer.

Ortlieb, Renate, Barbara Sieben, and Gertraude Krell. 2012. Geschenkt Wird Einer Nichts - Oder Doch?: Festschrift für Gertraude Krell [Nothing is Given Away for Free - Or Is It?: Commemorative Publication for Gertraude Krell]. Mering: Rainer Hampp Verlag.

Patton, Michael Q. 2002. Qualitative Research and Evaluation Methods. 3rd ed. Thousand Oaks, CA: Sage Publications.

Plett, Angelika. 2006. "Ein Ganz Persönlicher Überblick über den Stand von Diversity Management in Deutschland" [A Very Personal Overview over the Status Quo of 
Diversity Management in Germany]. Gruppendynamik [Group Dynamic] 37 (1): 25-32. doi:10.1007/s11612-006-0005-0.

Pringle, Judith. K., and Irene Ryan. 2015. "Understanding Context in Diversity Management: A Multi-Level Analysis." Equality, Diversity and Inclusion: An International Journal 34 (6): 470-82. doi:10.1108/EDI-05-2015-0031.

Riccò, Rossella, and Marco Guerci. 2014. "Diversity Challenge: An Integrated Process to Bridge the 'Implementation Gap."' Business Horizons $57 \quad$ (2): 235-45. doi:10.1016/j.bushor.2013.11.007.

Ruegg-Stürm, Johannes. 2000. "Jenseits der Machbarkeit: Idealtypische Herausforderungen Tiefgreifender Unternehmerischer Wandelprozesse aus einer Systemisch-RelationalKonstruktivistischen Perspektive" [Beyond Feasibility: Ideal-Typical Challenges of Deep-Seated Change and Transformation Processes from a Systemic Relational Constructivistic Perspective]. In Organisatorischer Wandel und Transformation [Organisational Change and Transformation], edited by Georg Schreyoegg, 195-237. Wiesbaden: Managementforschung.

Schlötter, Peter. 2005. Vertraute Sprache und ihre Entdeckung: Systemaufstellungen sind kein Zufallsprodukt - der Empirische Nachweis [Familiar Language and Her Discovery: Systemic Constellation is no Product of Chance - The Empirical Evidence]. Heidelberg: Carl-Auer.

Schreyoegg, Georg, ed. 2000. Organisatorischer Wandel und Transformation: Managementforschung [Organisational Change and Transformation Management Research]. Wiesbaden: Gabler.

Schulz, André. 2009. Strategisches Diversitätsmanagement: Unternehmensführung im Zeitalter der kulturellen Vielfalt [Strategic Diversity Management: Management in the Age of Cultural Diversity]. 1st ed. Wiesbaden: Gabler.

Schulz von Thun, F. 2015a. “...Und Von Wem Stammt das Werte- Und Entwicklungsquadrat” [...And from Whom Is the Original Value- and Development Quadrant Model]. Systemischer Zeitschrift für Systemische Strukturaufstellungen [Systemic Magazine for Systemic Constellation] 3 (7): 98-108.

2015b. "Parcours im Wertequadrat, Parcours im Leben: Einige Anmerkungen zu Varga von Kibéds Syst巴-Wertequadrat" [Parcour in the Value Quadrant Model, Parcour in Life: Some Remarks to the Varga von Kibéd's Syst ${ }^{\circledR}$-Value Quadrant Model]. Systemischer Zeitschrift für Systemische Strukturaufstellungen 3 (7): 110-13.

Schwaninger, Markus. 2008. Intelligent Organizations. 2nd ed. Singapore: Springer Singapore Pte. Ltd.

Shore, Lynn M., Beth G. Chung-Herrera, Michelle A. Dean, Karen H. Ehrhart, Don I. Jung, Amy E. Randel, and Gangaram Singh. 2009. "Diversity in Organizations: Where Are We Now and Where Are We Going?" Emerging Trends in Human Resource Management Theory and Research 19 (2): 117-33. doi:10.1016/j.hrmr.2008.10.004.

Simon, Fritz B. 2004. Gemeinsam sind wir blöd!? Die Intelligenz von Unternehmen, Managern und Märkten [Combined We Are Stupid!? The Intelligence of Companies, Managers and Markets]. Heidelberg: Carl Auer.

2009. Einführung in die Systemische Organisationstheorie [Introduction to the Systemic Theory of Organization]. 2nd ed. Heidelberg: Carl Auer.

2011. Einführung in Systemtheorie und Konstruktivismus [Introduction to Systemic Theory and Constructivism]. 5th ed. Heidelberg: Carl Auer.

Sparrer, Insa. 2007. Miracle, Solution and System: Solution-Focused Systemic Structural Constellations for Therapy and Organisational Change. Cheltenham: Solutions Books. 2009a. Systemische Strukturaufstellungen: Theorie und Praxis [Systemic Constellation: Theory and Practice]. 2nd ed.. Heidelberg: Carl Auer. 
2009b. Wunder, Lösung und System: Lösungsfokussierte Systemische Strukturaufstellungen für Therapie und Organisationsberatung [Miracle, Solution and System: Solution-Focused Systemic Structural Constellations for Therapy and Organisational Change]. 5th ed. Heidelberg: Carl Auer.

Sparrer, Insa, and Matthias Varga von Kibéd. 2010. Klare Sicht im Blindflug: Schriften zur Systemischen Strukturaufstellung [Clear View While Flying Blind: Scriptures for Systemical Structural Constellation]. Heidelberg: Carl Auer.

Süß, Stefan. 2010. "Quo Vadis Diversity-Management: Legitimationsfassade oder Professionelles Management Personeller Vielfalt?" [Quo Vadis Diversity Management: Face of Legitimation or Professional Management of Personnel Diversity?]. Zeitschrift für Management [Journal for Management] 5 (3): 283-304. doi:10.1007/s12354-0100128-7.

Süß, Stefan, and Markus Kleiner. 2008. "Dissemination of Diversity Management in Germany: A New Institutionalist Approach.” European Management Journal 26 (1): 35-47. doi:10.1016/j.emj.2007.10.003.

Syed, Jawad, and Mustafa Özbilgin. 2009. “A Relational Framework for International Transfer of Diversity Management Practices." International Journal of Human Resource Management 20 (12): 2435-53.

Tatli, Ahu. 2011. "A Multi-Layered Exploration of the Diversity Management Field: Diversity Discourses, Practices and Practitioners in the UK." British Journal of Management 22 (2): 238-53. doi:10.1111/j.1467-8551.2010.00730.x.

Tatli, Ahu, and Mustafa F. Özbilgin. 2009. "Understanding Diversity Managers' Role in Organizational Change: Towards a Conceptual Framework." Canadian Journal of Administrative Science 26 (3): 244-58. doi:10.1002/cjas.107.

Von Taube, Dagmar. 2015. "Deutschlands Haltung zu Kindern ist Katastrophal" [German Attitude towards Children Is Catastrophic]. Die Welt. Accessed June 22, 2016. http://www.welt.de/icon/article144989931/Deutschlands-Haltung-zu-Kindern-ist -katastrophal.html.

Thomson Reuters Foundation. 2015. "The 5 Key Issues Facing Women Working in the G20." Accessed May 28, 2016. http://www.womenatworkpoll.com.

Ullrich, Jan, Helen Pluut, and Marion Büttgen. 2015. "Gender Differences in the Family: Relatedness of Relocation Decisions.” Journal of Vocational Behavior 90 (10): 1-12. doi:10.1016/j.jvb.2015.06.003.

Varga von Kibéd, Matthias. 2006. "Solution-Focused Transverbality: How to Keep the Essence of the Solution-Focused Approach by Extending It." In Solution-Focused Management, edited by Guenter Lueger, 41-54. Munich: Hampp Munich.

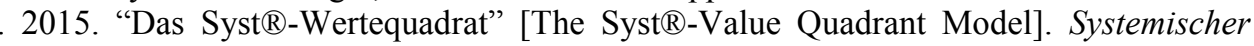
Zeitschrift für Systemische Strukturaufstellungen [Systemic Magazine for Systemic Constellation Practice] 3 (6): 12-32.

Varga von Kibéd, Matthias, and Insa Sparrer. 2011. Ganz im Gegenteil: Tetralemmaarbeit und andere Grundformen Systemischer Strukturaufstellungen - für Querdenker und Solche, die es Werden Wollen [On the Contrary: Tetralemma and Other Formats of Structural Constellation - for Unconventional Thinkers and for Those Who Would Like to Become One]. 7th ed. Heidelberg: Carl Auer.

Vedder, Günther. 2009. "Diversity Management: Grundlagen und Entwicklung im Internationalen Vergleich" [Diversity Management: Basic and Development, an International Comparison]. In Gender und Diversity: Albtraum oder Traumpaar? [Gender and Diversity: Nightmare or Dream Couple?], edited by Sünne Andresen, Mechthild Koreuber, and Dorothea Lüdke, 111-132. Wiesbaden: VS Verlag für Sozialwissenschaften. 
Vorhemus, Ursula. 2015a. Systemische Strukturaufstellungen (Syst $\left.{ }^{\circledR}\right): \quad$ Systemisch Konstruktivistisch - Phänomenologisch [Systemic Structural Constellation (Syst $\left.{ }^{\circledR}\right)$ : Systemic - Constructivist - Phenomenological]. Aachen: Ferrarimedia.

2015b. Systemische Strukturaufstellungen (Syst $\left.{ }^{\circledR}\right)$ : Transverbal, Grammatisch [Systemic Structural Constellation (Syst $\AA)$ : Transverbal, Grammatical]. Aachen: Ferrarimedia.

2015c. Systemische Strukturaufstellungen (Syst $\left.{ }^{\circledR}\right)$ : Hypnosystemisch, Lösungsfokussiert [Systemic Structural Constellation (Syst $\left.{ }^{\circledR}\right)$ :Hypnosystemic, Solution-Focused]. Aachen: Ferrarimedia.

Weber, Gunthard, and Claude Rosselet, eds. 2016. Praxis der Organisationsaufstellung [Practice of Systemic Constellation]. 3rd ed. Heidelberg: Carl Auer.

Weinert, Stephan. 2012. "Diversity der DAX30-Vorstände: Anspruch und Wirklichkeit" [Diversity of the DAX30 Board Members: Between Claim and Reality]. Research Report of the Faculty of Business of the University Düsseldorf. Unpublished manuscript. Last modified May 28, 2016. http://fhdd.opus.hbz-nrw.de/volltexte /2012/718.

Weinhold, Jan, Annette Bornhäuser, Christina Hunger, and Jochen Schweitzer. 2014. Dreierlei Wirksamkeit: Die Heidelberger Studie zu Systemaufstellungen [Three Ways of Effectiveness: The Heidelberger Study for Systemic Constellation]. Heidelberg: CarlAuer.

Wentling, Rose M. 2004. "Factors that Assist and Barriers that Hinder the Success of Diversity Initiatives in Multinational Corporations." Human Resource Development International 7 (2): 165-80.

Wittgenstein, Ludwig. 1922. “Tractatus Logico-Philosophicus.” London: Kegan Paul. Accessed November 7, 2015. http://people.umass.edu/klement/tlp/tlp.pdf.

\section{ABOUT THE AUTHORS}

Dr. Carmen A. Finckh: Professor, ESB Business School, University of Reutlingen, Reutlingen, Germany

Dr. Kerstin Reich: Professor, TEC Faculty, University of Reutlingen, Reutlingen, Germany 
The International Journal of Organizational Diversity is one of four thematically focused journals in the family of journals that support the Diversity knowledge community-its journals, book series, conference and online community. It is a section of The International Journal of Diversity in Organizations, Communities and Nations.

"Managing diversity" has emerged as a distinct agenda in the business and economics of diversity. This focus encompasses organizational diversity in private, public, and community organizations, including workplace culture, recruitment and promotion, human resource development, team work and relationships with diverse clienteles.

The International Journal of Organizational Diversity includes analyses of the impact of government and regulatory policies on workplace diversity and discusses various management practices that promote and encourage inclusivity. It explores the local and global diversity, as well as the full range of issues of diversity arising in workplaces, from gender, to sexual orientation, to culture and language, to disability.
As well as papers of a traditional scholarly type, this journal invites case studies that take the form of presentations of diversity practice-including documentation of socially-engaged practices and exegeses analyzing the effects of those practices.

The International Journal of Organizational Diversity is a peer-reviewed scholarly journal. 